\title{
Evidence for Interactions among Soybean Protein, Actin and $\alpha$-Actinin
}

\author{
Michio Muguruma ${ }^{*}$, Liang-Chuan $\operatorname{LIN}^{* *}$ and Tatsumi ITo* \\ * Department of Animal Science, Faculty of Agriculture, Kyushu University, \\ 6-10-1, Hakozaki, Higashi-ku, Fukuoka 812 \\ ${ }^{* *}$ National Chung Hsing University, 250, Kuokuang Road Taichung, \\ Taiwan, Republic of China
}

\begin{abstract}
To improve the utilization of soybean proteins in meat products, the interaction of $\alpha$-actinin and soybean protein with actin was investigated by cosedimentation and viscosity experiments. Analyses of the sedimented proteins clearly demonstrated that soybean proteins can bind to $\mathrm{F}$-actin filaments to some extent under neutral (7.5) or slightly acidic (5.5) $\mathrm{pH}$ conditions at $25^{\circ} \mathrm{C}$. However, no interaction between $\alpha$-actinin and soybean proteins was observed. In the presence or absence of soybean protein, no appreciable differences were obsered in the amount of $\alpha$-actinin that bound to $\mathrm{F}$-actin under neutral $\mathrm{pH}$ condition. However, the amount of $\alpha$-actinin that bound to $\mathrm{F}$-actin in the absence of soybean proteins was greater than that of $\alpha$-actinin that bound to $\mathrm{F}$-actin in the presence of soybean proteins under acidic $\mathrm{pH}$ condition. These results indicated that $\alpha$-actinin and soybean protein can bind to actin filaments simultaneously. By viscometry it was confirmed that $a$-actinin and soybean proteins can bind to $\mathrm{F}$-actin.
\end{abstract}

Soybeans are recognized as a high-protein human food source. Recently, soybean protein has been used in fabricated foods such as meat patties and emulsion type sausage in order to modify the functional properties and nutritional value ${ }^{1)}$. To develop technology for effective utilization of soybean protein in meat industry, it is very important to understand the mechanism of interaction between soybean proteins and muscle proteins. Although the binding of soybean protein to myosin $\mathrm{B}$ or myosin has been studied extensively ${ }^{2) \sim 6)}$, very little is known about the binding of soybean protein to purified myofibrillar proteins, such as actin, which constitutes about $22 \%$ of the myofibrillar protein mass ${ }^{7)}$, and $\alpha$-actinin, that cross-links to actin filaments ${ }^{8)}$ and accelerates the polymerization of actin from the globular to the fibrous form ${ }^{9}$.

We reported previously ${ }^{10)}$ that $\alpha$-actinin was released from myosin $B$ complex when myosin $B$ was mixed with soybean protein, therefore, we suggested that soybean protein had greater affinity for actin than for $a$-actinin. In the present study purified actin and $\alpha$-actinin were used to further examine the interaction of soybean protein with actin and the effect of $\alpha$-actinin on the interaction between them.

\section{Materials and Methods}

\section{Preparation of proteins}

G-actin was prepared from acetone powder of rabbit skeletal muscle by the method of SPUDICH and W $\mathrm{ATT}^{11)}$ and was purified further on a Sephacryl S-200 column. $\alpha$-Actinin was purified from rabbit skeletal muscle according to the method of SUzUKi et al. ${ }^{122}$. Soybean $7 \mathrm{~S}$ and $11 \mathrm{~S}$ components were prepared by the method reported previously ${ }^{10)}$. F-actin was prepared from G-actin by polymerization at 25 ${ }^{\circ} \mathrm{C}$ for $30 \mathrm{~min}$ in a solution containing $10 \mathrm{mM}$ Tris-acetate ( $\mathrm{pH} 7.5), 100 \mathrm{mM} \mathrm{KCl}, 1 \mathrm{mM}$ ATP, $0.2 \mathrm{mM} \mathrm{CaCl}_{2}$ and $5 \mathrm{mM} \beta$-mercaptoethanol. Soybean protein was prepared by mixing the $7 \mathrm{~S}$ and $11 \mathrm{~S}$ components at $1: 1$ weight ratio. 
Binding assay of $\alpha$-actinin and soybean protein with actin

All protein solutions were centrifuged before use at $80000 \times \mathrm{g}$ for $30 \mathrm{~min}$ at $2^{\circ} \mathrm{C}$ in order to remove aggregates. Protein solutions $(600 \mu l$ total volume) containing constant amounts of $a$-actinin $(0.6 \mathrm{mg})$, soybean protein $(3 \mathrm{mg})$ and $\mathrm{F}$-actin $(0.6 \mathrm{mg})$ were incubated in a solution containing $400 \mathrm{mM} \mathrm{KCl}, 1 \mathrm{mM} \mathrm{NaN}, 10 \mathrm{mM}$ $\beta$-mercaptoethanol and $10 \mathrm{mM}$ Tris-acetate $(\mathrm{pH} \mathrm{7.5)}$ or $10 \mathrm{mM}$ acetate buffer $(\mathrm{pH} \mathrm{5.5)}$ at $25^{\circ} \mathrm{C}$ for $30 \mathrm{~min}$, then centrifuged with a Hitachi $65 \mathrm{P}-7$ ultracentrifuge at $80000 \times \mathrm{g}$ for $30 \mathrm{~min}$ or $10000 \times \mathrm{g}$ for $20 \mathrm{~min}$ at $\mathrm{pH} 7.5$ or $\mathrm{pH} 5.5$, respectively. Then $30 \mu l$ of supernatant was added to $100 \mu \mathrm{l}$ of a tracking dye, which contained $8 \%$ SDS, $60 \%$ glycerol, $0.4 \%$ bromophenol blue, $200 \mathrm{mM}$ Tris- $\mathrm{HCl}$, $\mathrm{pH} 6.8$. Subsequently, $25 \mu l$ of $\beta$-mercaptoethanol was added, and the solution was immediately boiled for $3 \mathrm{~min}$. The precipitates were homogenized in $600 \mu l$ of $400 \mathrm{mM} \mathrm{KCl}, 1 \mathrm{mM} \mathrm{NaN}, 10 \mathrm{mM}$ $\beta$-mercaptoethanol, $10 \mathrm{mM}$ Tris-acetate $(\mathrm{pH}$ $7.5)$ or $10 \mathrm{mM}$ acetate buffer ( $\mathrm{pH} 5.5)$, plus 200 $\mu l$ of the tracking dye and $50 \mu l$ of $\beta-$ mercaptoethanol, and the solution was boiled for $3 \mathrm{~min}$. Volumes were kept constant so that precipitate to precipitate, supernatant to

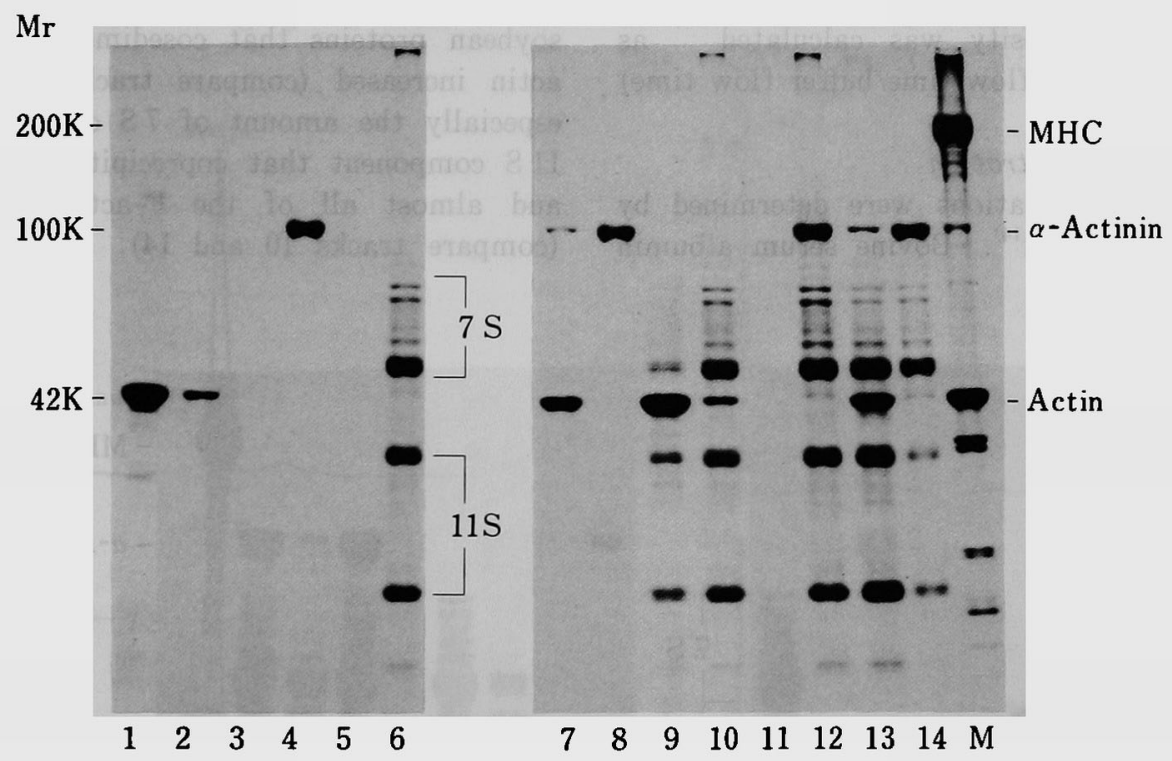

Fig. 1 Electrophoretic analysis of binding of $\alpha$-actinin and soybean protein to actin filaments at $\mathrm{pH} 7.5$

Proteins were added to incubation tubes in the order listed below and centrifuged at $80000 \times \mathrm{g}$ for $30 \mathrm{~min}$ at $25^{\circ} \mathrm{C}$. Odd numbers and even numbers represent precipitates and supernatant fractions respectively. Tracks 1 and 2 contained $F$-actin. Tracks 3 and 4 contained $\alpha$-actinin. Tracks 5 and 6 contained soybean protein. Tracks 7 and 8 contained mixture of $\alpha$-actinin and $\mathrm{F}$-actin. Tracks 9 and 10 contained the mixture of soybean protein and F-actin. Tracks 11 and 12 contained the mixture of $\alpha$-actinin and soybean protein. Tracks 13 and 14 contained the mixture of $\alpha$-actinin, soybean protein and $F$-actin. Track $M$ contained myofibrils as a standard.

MHC; myosin heavy chain, $7 \mathrm{~S}$; soybean protein $7 \mathrm{~S}$ component, $11 \mathrm{~S}$; soybean protein $11 \mathrm{~S}$ component 
supernatant and precipitate to supernatant comparisons was able to be made.

SDS-polyacrylamide gel electrophoresis

SDS-polyacrylamide gel elctrophoresis (SDSPAGE) was performed on $7.5 \sim 17.5 \%$ acrylamide gradient slab gels according to the method of LAEMMLI ${ }^{13)}$. Samples were applied to gels in $10 \mu l$ aliquots. Densitometric scan of the gels was performed with a Hitachi 557 Double Wavelength-Double Beam Spectrophotometer.

\section{Viscometry}

The viscosities of protein solution were determined with an Ostwald viscometer, with a flow time of $30 \mathrm{sec}$ for buffer. The temperature was maintained at $25^{\circ} \mathrm{C}$ with a water bath. The specific viscosity was calculated as follows : (sample flow time/buffer flow time) -1 .

\section{Protein concentration}

protein concentrations were determined by the biuret method ${ }^{14)}$. Bovine serum albumin was used as a standard.

\section{Results}

Interaction of $\alpha$-actinin and/or soybean protein with $F$-actin filaments in sedimentation assays as assessed by SDS-PAGE

Fig. 1 shows the interaction of $\alpha$-actinin and soybean protein with $\mathbf{F}$-actin filaments at $\mathrm{pH}$ 7.5. Approximately $90 \%$ of the $\mathbf{F}$-actin sedimented (compare tracks 1 and 2), while $\alpha$-actinin and soybean proteins remained in the supernatants (tracks 4 and 6). Under the conditions employed, a significant portion of $11 \mathrm{~S}$ components of the soybean proteins was bound by $\mathrm{F}$-actin and precipitated (track 9). When $\alpha$-actinin was present, the amount of soybean proteins that cosedimented with Factin increased (compare tracks 9 and 13), especially the amount of $7 \mathrm{~S}$ component and $11 \mathrm{~S}$ component that coprecipitated increased and almost all of the F-actin sedimented (compare tracks 10 and 14). Mixing of $\alpha$ -

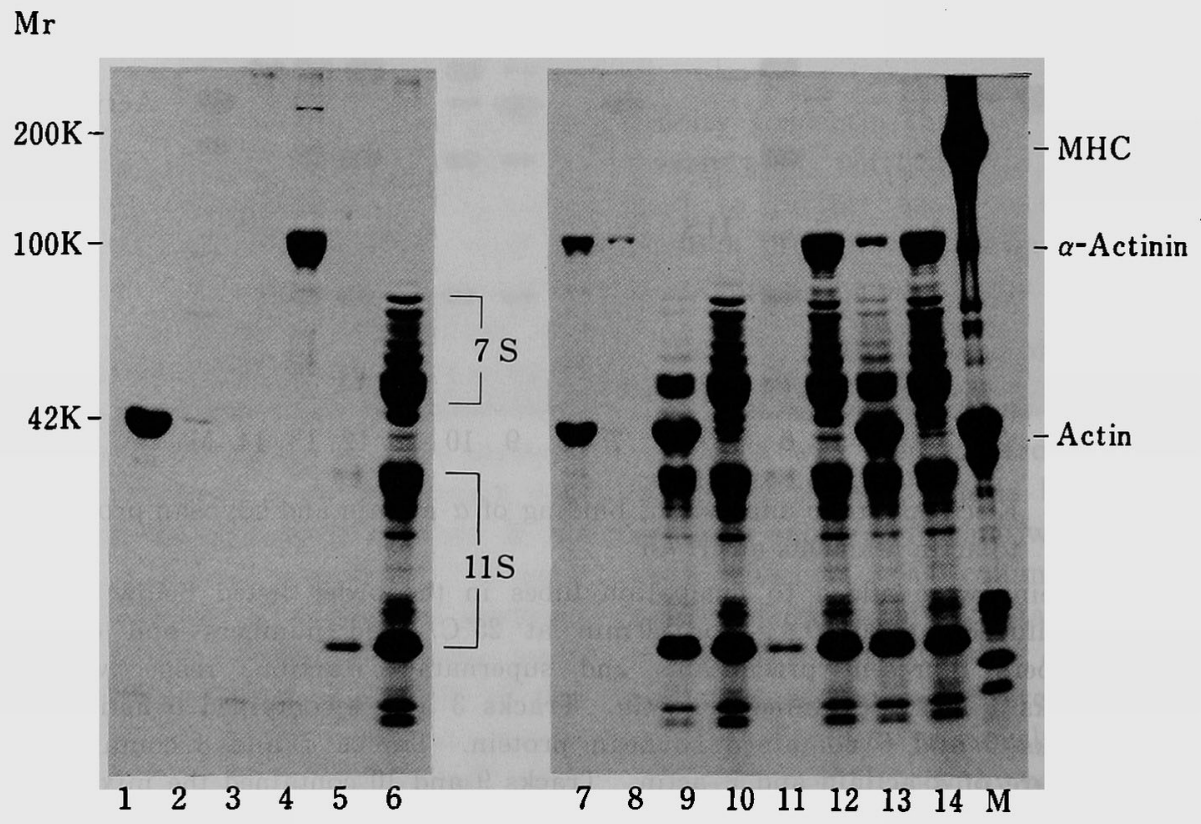

Fig. 2 Electrophoretic analysis of binding of $\alpha$-actinin and soybean proteins to actin filaments at $\mathrm{pH} 5.5$

Proteins were added to incubation tubes as described in the legend to Fig. 1 and centrifuged at $10000 \times \mathrm{g}$ for $20 \mathrm{~min}$ at $25^{\circ} \mathrm{C}$. All indications and abbreviations are the same as in Fig. 1. 
actinin and soybean protein in the absence of F-actin did not produce a sedimentary complex (track 11). At pH 5.5 (Fig. 2), most of the F-actin sedimented (track 1 ), while almost all of $\alpha$-actinin and soybean proteins remained in the supernatants (tracks 4 and 6). Mixing of $\alpha$-actinin and soybean proteins at $\mathrm{pH} 5.5$, as in the case of $\mathrm{pH} 7.5$, did not produce a sedimentary complex. The amount of $\alpha$-actinin that cosedimented with $\mathrm{F}$-actin markedly increased with the decrease of $\mathrm{pH}$ value (compare Fig. 1-7 and Fig. 2-7). However, the amount of $a$-actinin that cosedimented with $\mathrm{F}$-actin decreased when soybean protein was added to the mixture of $\alpha$-actinin and $\mathrm{F}$-actin (compare tracks 7 and 13). Changing the order of the
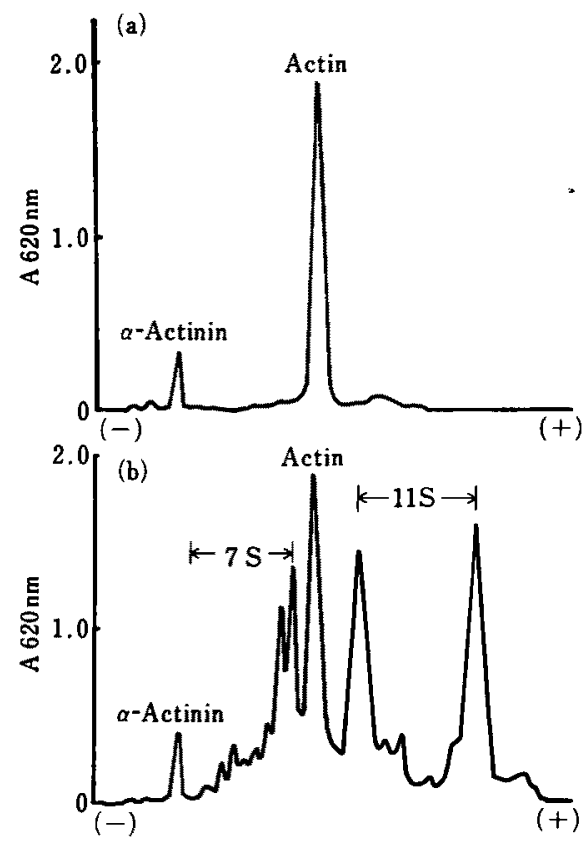

Fig. 3 Densitometric scans of SDS-PAGE slab gel of precipitated proteins after the centrifugation of the mixture of actin and $\alpha$-actinin with and without addition of soybean proteins at $\mathrm{pH} 7.5$

(a), densitometric scan of gel 7 in Fig. 1. (b), densitometric scan of gel 13 in Fig. 1. $7 \mathrm{~S}$; soybean protein $7 \mathrm{~S}$ component, $11 \mathrm{~S}$; soybean protein $11 \mathrm{~S}$ component addition of $\alpha$-actinin, soybean protein and F-actin had no effect on the results obtained throughout the experiments.

The amount of $\alpha$-actinin that cosedimented with $\mathrm{F}$-actin in the presence or absence of the soybean proteins was determined by densitometry. The results obtained at $\mathrm{pH} 7.5$ are shown in Fig. 3. The molar ratio of $\alpha$-actinin (native molecular weigth of 200000) to Gactin (molecular weight of 42000 ) in each incubation tube before centrifugation was 1 : 4.7. The molar ratio of sedimented $\alpha$-actinin to G-actin was $1: 40$ in the absence of soybean protein (Fig. 3-a). When soybean protein was present (Fig. 3-b), however, the ratio of $\alpha$ actinin cosedimented with the $\mathrm{F}$-actin precipitate slightly increased (the molar ratio of
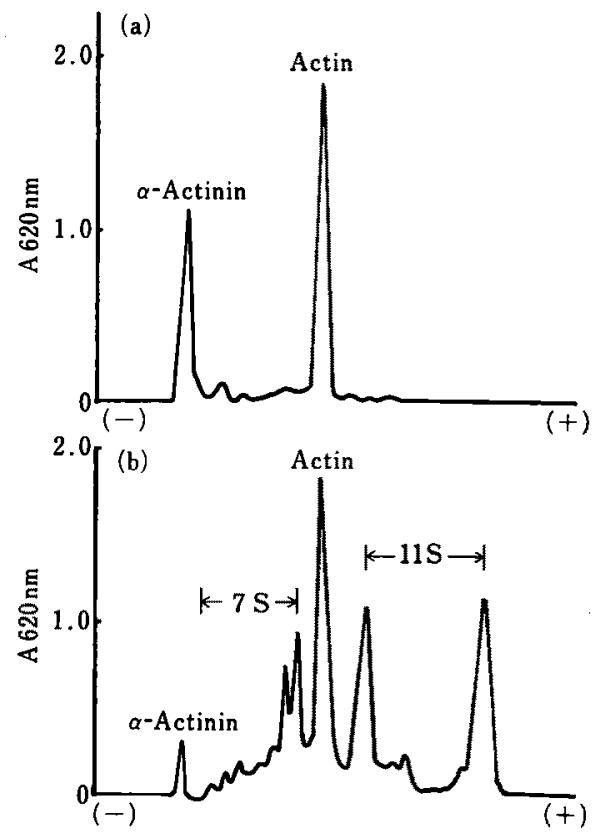

Fig. 4 Densitometric scans of SDS-PAGE slab gels of precipitated protein after the centrifugation of the mixture of actin and $a$-actinin with and without addition of soybean proteins at $\mathrm{pH} 5.5$

(a), densitometric scan of gel 7 in Fig. 2. (b), densitometric scan of gel 13 in Fig. 2. All abbreviations are the same as in Fig. 3. 
$\alpha$-actinin to actin was $1: 32$ ). Fig. 4 also shows densitometric scans of gels at pH 5.5. The molar ratio of $\alpha$-actinin to actin was $1: 6.75$ in the absence of soybean protein but it was decreased to $1: 32$ in the presence of soybean protein. The amount of $\alpha$-actinin that cosedimented with $\mathrm{F}$-actin in the absence of soybean protein at $\mathrm{pH} 5.5$ was about 6 fold greater than that at $\mathrm{pH} 7.5$. However, the amount of sedimented $\alpha$-actinin with $\mathrm{F}$-actin in the presence of soybean protein at $\mathrm{pH} 7.5$ was almost the same as at $\mathrm{pH} 5.5$. Thus, soybean proteins had a stronger effect on the binding of $\alpha$-actinin with $\mathrm{F}$-actin at a slightly acidic $\mathrm{pH}$ value of 5.5 .

Effect of $\alpha$-actinin and soybean protein on the polymerization of actin

Although the optimum concentration of $\mathrm{KCl}$ for polymerization of skeletal muscle actin is around $0.1 \mathrm{M}^{15)}$, soybean protein dissociates

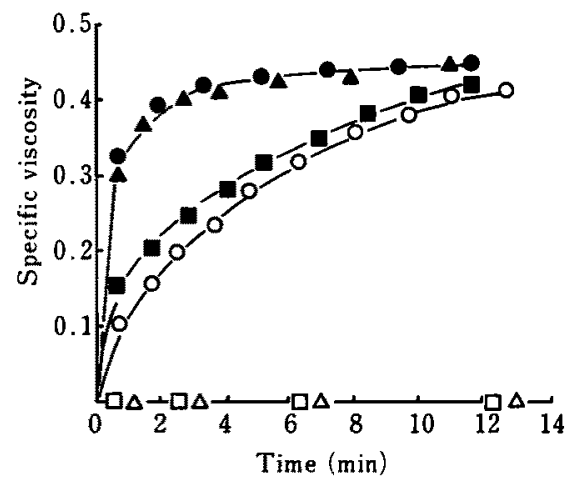

Fig. 5 Effect of soybean protein on the polymerization of $\mathrm{G}$-actin accelerated by $\alpha$-actinin at $\mathrm{pH} 7.5$

All experiments were carried out in a solution of $0.5 \mathrm{mM}$ ATP, $2 \mathrm{mM}$ dithiothreitol, $1 \mathrm{mM} \mathrm{NaN}_{3}, 0.5 \mathrm{mM} \mathrm{CaCl} 2$ and $10 \mathrm{mM}$ Tris-acetate $\left(\mathrm{pH} \mathrm{7.5)}\right.$ at $25^{\circ} \mathrm{C}$. Polymerization was induced by the addition of $\mathrm{KCl}$ to a final concentration of $0.4 \mathrm{M}$, and the viscosity was measured with an Ostwald type viscometer at $25^{\circ} \mathrm{C}$. 0 . G-actin $(0.75 \mathrm{mg} / \mathrm{ml}) ; \Delta, \alpha$-actinin $(0.17 \mathrm{mg} / \mathrm{ml}) ; \square$, soybean protein $(0.61$ $\mathrm{mg} / \mathrm{ml}) ; \boldsymbol{\Delta}, \mathrm{G}$-actin $+\alpha$-actinin ; $\mathbf{Q}, \mathrm{G}-$ actin + soybean protein; $-\mathrm{G}-$ actin $+\alpha-$ actinin + soybean protein into subunits under such low ionic strength ${ }^{16) 17)}$. In the present study, therefore, the polymerization of actin was induced by the addition of $\mathrm{KCl}$ to a final concentration of $0.4 \mathrm{M}$. $a-$ Actinin accelerates polymerization of Gactin $^{9)}$. The effect of soybean protein on the polymerization of actin accelerated by $\alpha$ actinin at $\mathrm{pH} 7.5$ was examined with an Ostwald viscometer, and the result is shown in Fig. 5. $\alpha$-Actinin caused a marked increase in the rate of actin polymerization in the presence of high concentration of $\mathrm{KCl}$ (filled triangles), whereas soybean protein caused little increase in polymerization rate (filled squares). In addition, soybean proteins did not interfere the effect of $a$-actinin in accelerating the polymerization of actin (filled circles).

At pH 5.5 (Fig. 6), addition of high concentration of $\mathrm{KCl}(0.4 \mathrm{M})$ to the actin solution resulted in a relatively small increase in

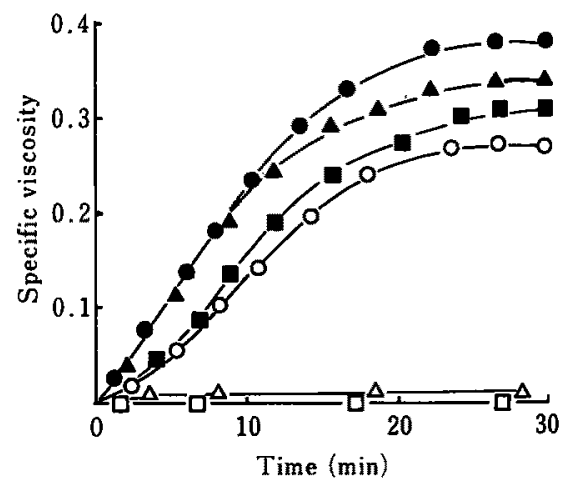

Fig. 6 Effect of soybean protein on the polymerization of $\mathrm{G}$-actin accelerated by $\alpha$-actinin in $\mathrm{pH} 5.5$

All experiments were carried out in a solution of $0.5 \mathrm{mM}$ ATP, $2 \mathrm{mM}$ dithiothreitol, $1 \mathrm{mM} \mathrm{NaN}, 0.5 \mathrm{mM} \mathrm{CaCl}_{2}$ and $10 \mathrm{mM}$ acetate buffer (pH5.5) at $25^{\circ} \mathrm{C}$. Polymerization was induced by the addition of $\mathrm{KCl}$ to a final concentration of $0.4 \mathrm{M}$, and the viscosity was measured with an Ostwald type viscometer at $25^{\circ} \mathrm{C}$. $O$, G-actin $(0.9 \mathrm{mg} / \mathrm{ml}) ; \triangle, \alpha$-actinin $(0.2$ $\mathrm{mg} / \mathrm{ml}) ; \square$, soybean protein $(0.73 \mathrm{mg} /$ $\mathrm{ml}) ; \boldsymbol{\Delta}, \mathrm{G}$-actin $+\alpha$-actinin; $\mathbf{\boldsymbol { U }}, \mathrm{G}$-actin + soybean protein;, $\mathrm{G}$-actin $+\alpha$-actinin + soybean protein 
viscosity when it was compared with $\mathrm{pH} 7.5$ (open circles). Actin polymerization was accelerated by $\alpha$-actinin (filled triangles). The effects of soybean proteins on the rate of actin polymerization in the presence of $\alpha$-actinin were similar to those at $\mathrm{pH} 7.5$ (filled circles). However, the final viscosity reached in the presence of soybean proteins was slightly higher than that in its absence (filled circles). $a$-Actinin alone had a detectable viscosity (open triangles).

\section{Discussion}

Although thermal treatment above $75 \sim 85^{\circ} \mathrm{C}$ is required for the interaction between soybean protein and $\operatorname{myosin}^{45)}$, electrophoretic analyses of the sedimented proteins clearly demonstrates that soybean proteins can bind to $\mathrm{F}$ actin filaments to some extent under neutral (7.5) or slightly acidic (5.5) $\mathrm{pH}$ conditions at $25^{\circ} \mathrm{C}$. $\mathrm{HAGA}^{18)}$ also suggested that the interaction might occur between actin and soybean protein. However, no interaction between $\alpha$ actinin and soybean proteins was observed under the present experimental conditions. GoLL et al. ${ }^{19)}$ showed that the amount of $a$-actinin that combined with $\mathrm{F}$-actin depended on temperature. The amount of $\alpha$-actinin that cosedimented with $\mathrm{F}$-actin at $25^{\circ} \mathrm{C}$ and $\mathrm{pH} 7.5$ was similar to their results, whereas the amount of $\alpha$-actinin that cosedimented with $\mathrm{F}$-actin at $25^{\circ} \mathrm{C}$ and $\mathrm{pH} 5.5$ was about 6 -fold of that at $\mathrm{pH} 7.5$.

It is known that paracrystals are formed by side-by-side association of $\mathrm{F}$-actin particles in the presence of $0.4 \mathrm{M} \mathrm{KCl}$ at $\mathrm{pH} 5.0^{20)}$. In this experiment, actin flaments were sedimented at $\mathrm{pH} 5.5$ by low speed centrifugation (Fig. 2-1), probably due to the formation of $\mathrm{F}$-actin paracrystals. KOBAYASHI and T ASHIMA ${ }^{21)}$ have reported that the isoelectric point of skeletal muscle $a$-actinin is 5.9 6.1. Prolonged exposure to low $\mathrm{pH}$ causes side-to-side aggregation of $a$-actinin ${ }^{12)}$. The present results (Fig. 2-7 and 4-a) suggest that the binding of $\alpha$-actinin to actin paracrystals and the conformational changes of $a$-actinin at low $\mathrm{pH}$ values may increase the cosedimentation of $\alpha$-actinin with
F-actin. In the presence or absence of soybean protein at $\mathrm{pH} 7.5$, no appreciable differences were observed in the amount of $\alpha$-actinin that cosedimented with F-actin (Figs. 1-7 and 113). Evidently, soybean protein does not interfere the interaction of $\alpha$-actinin and $\mathbf{F}$ actin. In the presence of $\alpha$-actinin at $\mathrm{pH} 7.5$, the amount of soybean proteins that cosedimented with $\mathrm{F}$-actin appreciably increased (Fig. 1-13). This may be due to the formation of $\mathrm{F}$-actin bundles induced by $\alpha$-actinin ${ }^{22) 23}$ following the binding of soybean proteins to $\mathrm{F}$-actin. When soybean proteins were incubated with $F$-actin and $\alpha$-actinin in the presence of $0.4 \mathrm{M} \mathrm{KCl}$ at $\mathrm{pH} 5.5$, the amount of $\alpha$-actinin that cosedimented with $\mathrm{F}$-actin decreased to the level of $\mathrm{pH} 7.5$. There were no differences in the amount of soybean proteins that cosedimented with F-actin (Fig. 2-13 and Fig. 4). These results suggest that the binding of soybean proteins to $F$-actin filaments inhibits the formation of actin paracrystals, so that the amount of $\alpha$-actinin that cosedimented with $F$-actin may be decreased.

$\alpha$-Actinin accelerates the rate of polymerization of $\mathrm{G}$-actin ${ }^{9)}$. Because $a$-actinin crosslinks $F$-actin filaments ${ }^{1222)}$, the addition of $a$-actinin to $F$-actin increases the viscosity of the $\mathrm{F}$-actin solution ${ }^{18)}$. $\alpha$-Actinin increased the viscosity of $\mathrm{F}$-actin even under high ionic strength and low pH conditions (Fig. 5 and 6). Because soybean proteins did not have a significant effect on actin viscosity, soybean proteins evidently do not bind with $\mathrm{F}$-actin by a cross-linking manner. By viscometry it was confirmed that soybean proteins did not interfere the interaction of $\alpha$-actinin and Factin under neutral condition. Thus, the binding of $\alpha$-actinin to $F$-actin and of soybean protein to $\mathrm{F}$-actin is not competitive in the presence of $0.4 \mathrm{M} \mathrm{KCl}$. However, under slightly acidic $\mathrm{pH}$ condition, the amount of $\alpha$-actinin that bound to $\mathrm{F}$-actin in the absence of soybean protein was greater than that of $\alpha$ actinin that bound to $F$-actin in the presence of soybean protein. Therefore, the present result supports the previous suggestion that the affinity of soybean protein for actin is 
stronger than that of $\alpha$-actinin under low ionic strength and low $\mathrm{pH}$ conditions. IIBUCHI and IMAHORI ${ }^{24)}$ described that the $7 \mathrm{~S}$ globulin was in a monomeric state at $\mathrm{pH} 3$ or at an ionic strength higher than 0.8 , while it was in a dimeric state at $\mathrm{pH} 6$ and at an ionic strength below 0.2 . Under the intermediate conditions it existed as a mixture of monomer and dimer. Thus, the effects of ionic strength and $\mathrm{pH}$ may not be small in the interaction between soybean proteins and $\alpha$-actinin with $\mathrm{F}$-actin. Furthermore, it is considered that the interaction between $7 \mathrm{~S}$ component and $11 \mathrm{~S}$ component may effect the interaction between soybean protein and muscle protein. Further investigations of the molecular mechanism for the interaction between soybean proteins and muscle proteins are required.

Acknowledgments: We would like to thank Professor T. FuKAzAwa for many valuable discussions and suggestions. We thank Fuji-Oil Company Limited for donating defatted soybean flakes.

\section{References}

1) Waggle, D.H., Decker, C.D. and Kolar, C.W.: J. Am. Oil Chem. Soc., 58, 341 (1981).

2) Yamamoto, K., Fukazawa, T. and Yasui, T. : Memories Fac. Agr. Hokkaido Univ., 9, 116 (1973).

3) Yamamoto, K., Ka.jiyama, $Y$. and SAMEJIMA, K.: J. College Dairying, 7, 39 (1977).

4) King, N.L. : J. Agric. Food Chem., 25, 166 (1977).

5) Peng, I.C., Dayton, W.R., Quass, D.W. and Allen, C.E. : J. Food Sci., 47, 1976 (1982).

6) Haga, S. and Ohashi, T.: Agric. Biol. Chem., 48, 1001 (1984).

7) Yates, L.D. and Greaser, M.L. : J. Mol. Biol., 168, 123 (1983).

8) Drabikowsky, W. and Nowak, E. : Eur. J. Biochem., 5, 209 (1968).

9) Maruyama, $K$. and Ebashi, S.: $J$. Biochem., 58, 13 (1965).

10) Lin, L.C. and Ito, T. : J. Food Technol., 20, 219 (1985).
11) Spudich, J.A. and WatT, S.: J. Biol, Chem., 246, 4866 (1971).

12) Suzuki, A., Goll, D.E., Singh, I., Allen, R.E., ROBSON, R.M. and STromer, M.H.: J. Biol. Chem., 251, 6860 (1976).

13) Laemmli, U.K. : Nature, 227, 680 (1970).

14) Gornall, A.G., Bardawill, C.J. and David, M.M. : J. Biol. Chem., 177, 751 (1949).

15) MASAKi, T., ENDo, M. and Ebashi, S. : $J$. Biochem., 62, 630 (1967).

16) Catsimpoolas, N., Rogers, D.A., Circle, S.J. and Meyer, E.W. : Cereal Chem., 44, 631 (1967).

17) Itвuchi, C. and Imahori, K. : Agric. Biol. Chem., 42, 31 (1978).

18) HAGA, S.: Kagaku to Seibutsu, 26, 104 (1988).

19) Golt, D.E., Suzuki, A., Temple, J. and Holmes, G.R.: J. Mol. Biol., 67, 469 (1972).

20) Kawamura, M. and Maruyama, K. : J. Biochem., 68, 885 (1970).

21) Kobayashi, R. and Tashima, Y. : Biochim. Biophys. Acta, 745, 209 (1983).

22) Podlubnaya, Z.A., Tskhovrebova, L.A., ZaAlishvili, M.M. and Stefanenko, G.A. : J. Mol. Biol., 92, 357 (1975).

23) Singh, I., Goll, D.E. and Robson, R.M.: Biochim. Biophys. Acta, 670, 1 (1981).

24) Iıвuchi, C. and Imahori, K. : Agric. Biol. Chem., 42, 25 (1978).

(Received Nov. 28, 1988)

$$
\begin{aligned}
& \text { 大豆蛋白質とアクチンおよひ } a \text {-アクチニン } \\
& \text { との相互作用 } \\
& \text { 六車三治男 * 林 亮全 }{ }^{* *} \text { ・伊藤裂躬 }{ }^{*} \\
& \text { *九州大学農学部 } \\
& \text { （广812 福岡市東区箱崎 6-10-1） } \\
& \text { ** 国立中興大学 }
\end{aligned}
$$

（中華民国台湾省台中市国光路 250）

大豆蛋白質の肉製品への有效利用に関する技術を改善 するため，大豆蛋白質と筋肉蛋白質であるアクチンおよ び $a$ アクチニンとの相互作用について遠心法および粘 度測定法により検討した。その結果，大豆蛋白質は 25 ${ }^{\circ} \mathrm{C}$ 中性 (7.5) および弱酸性 (5.5) の pH 条件下で Fアクチンに結合することができた：しかし，中性および 弱酸性の $\mathrm{pH}$ 条件下で, 大豆蛋白質と $\alpha$-アクチニンと 
の相互作用は認められなかったＦ-アクチンに $\alpha$-アク チニンが結合することは良く知られているが，中性の $\mathrm{pH}$ 条件下では大豆蛋白質の存在に関わりなくそれらの 結合量に変化は認められなかった。しかし，弱酸性の $\mathrm{pH}$ 条件下では大豆蛋白質が存在しない場合に $\mathrm{F}$-アク
チンに結合する $\alpha$-アクチニンの量は大豆蛋白質が存在 する場合上りあかなり多かった， $\alpha$ ーアクチニンは F-ア クチンを架橋結合することにより F-アクチン溶液の粘 度を増加させるが，大豆蛋白質の添加は $\alpha$-アクチニン の作用に影響を及ばさなかった。 